Canadian University Music Review

Revue de musique des universités canadiennes

\title{
A New Gloria for Satie's Messe des pauvres
}

\section{Erich Schwandt}

Volume 18, numéro 2, 1998

URI : https://id.erudit.org/iderudit/1014653ar

DOI : https://doi.org/10.7202/1014653ar

Aller au sommaire du numéro

\section{Éditeur(s)}

Canadian University Music Society / Société de musique des universités canadiennes

\section{ISSN}

0710-0353 (imprimé)

2291-2436 (numérique)

Découvrir la revue

\section{Citer cet article}

Schwandt, E. (1998). A New Gloria for Satie's Messe des pauvres. Canadian University Music Review / Revue de musique des universités canadiennes, 18(2), 38-47. https://doi.org/10.7202/1014653ar
Résumé de l'article

Erik Satie worked on his Messe des pauvres from 1893 to 1895 but never completed it. After Satie's death, Darius Milhaud selected movements from the composer's notebooks and published them in 1929 as the Messe des pauvres for organ and voices. The Mass is missing its Gloria; however, the only contemporary account suggests that the Gloria was in existence in 1895. The object of this article is to propose a new Gloria based on one of Satie's contemporaneous piano préludes. As well, to involve the singers more fully, two very short movements are furnished with Latin texts.
All Rights Reserved (C Canadian University Music Society / Société de musique des universités canadiennes, 1998
Ce document est protégé par la loi sur le droit d'auteur. L’utilisation des services d'Érudit (y compris la reproduction) est assujettie à sa politique d'utilisation que vous pouvez consulter en ligne.

https://apropos.erudit.org/fr/usagers/politique-dutilisation/ 


\title{
A NEW GLORIA FOR SATIE'S MESSE DES PAUVRES
}

\author{
Erich Schwandt
}

Erik Satie's Messe des pauvres, a work for organ and voices, was composed in the mid 1890s, but published only in 1929 by Rouart, Lerolle \& Cie. For reasons unknown, the publisher was given only selected movements of the Mass, and these movements are in various stages of completeness. Robert Orledge remarks that the Kyrie, in its published form, is probably unfinished; that the Gloria is lost; and that the psalm, the prières, and invocations are sometimes slightly confused. ${ }^{1}$ The printed edition thus may not truly represent Satie's intentions or reflect his own conception of the work.

It is not known for what purpose or occasion the Messe des pauvres was composed; moreover, there is no satisfactory explanation of the meaning of the title. The Mass cannot have been intended for performance at Satie's one-man Église Métropolitaine de l'Art de Jésus Conducteur, for he was not only its sole parcier ("shareholder") and its only maître de chapelle; he was also its only member. ${ }^{2}$ His fictitious "Abbey" was the small room at number 6, rue Cortot, Paris, where "Monsieur le Pauvre"-as Satie styled himself about 1895lived. Whether the Mass was intended for an actual church in Paris or its suburbs is also unknown. However, if the Mass was originally meant to be a work with movements for organ and voices and movements for organ alone, it is strange that almost half of the movements look like piano transcriptions or arrangements of organ pieces.

The physical layout and general appearance of the printed edition lend weight to Orledge's statement that the Mass is incomplete. The Mass's movements, as determined by Orledge, are: ${ }^{3}$

1 Robert Orledge, Satie the Composer (Cambridge: Cambridge University Press, 1990), $278 \mathrm{ff}$. See also pp. 164, 186, and 211. The unfinished state of the Messe des pauvres suggests that Satie did not publish the Mass himself; however, Orledge, relying on the erroneous copyright notice in the RouartLerolle/Salabert edition, gives 1920 as the year of publication. This date is contradicted by Darius Milhaud, Notes without Music (London: D. Dobson, 1952), 150, who states that, as Satie's musical executor, he arranged to have the Mass published by Rouart-Lerolle. Rollo H. Myers, Erik Satie (London: D. Dobson, 1948; repr. ed., New York: Dover, 1968), 149, lists the Mass as posthumous, and Alan Gillmor, Erik Satie (Boston: Twayne, 1988), 329, gives the correct year, 1929. See note 11.

2Gillmor, Erik Satie, $90 \mathrm{f}$. See also Orledge, Satie the Composer, 11-14.

3 Orledge, Satie the Composer, 279. 


\section{Messe des pauvres}

1. Prélude

2. Kyrie

3. Dixit Dominus 5

4. Prière des orgues

5. Gloria in excelsis ${ }^{6}$

6. Commune qui mundi nefas

7. Chant ecclésiastique

8. Prière pour les voyageurs et les marins en danger de mort, à la très bonne et très auguste Vierge Marie, mère de Jésus ${ }^{7}$

9. Prière pour le salut de mon âme

Four of the movements, numbers 1, 2, 4, and 6, are in normal three-stave organ score. Three movements, numbers 3,7 , and 8 (the first harmonization), are in two-stave score, for performance on the manuals alone. Number 8 (the second harmonization), with its massive left-hand chords and its low AAs and GGs is very pianistic. Number 9 may be a piano transcription of an organ piece that originally alternated pedal solos with harmonized statements of the solos for manuals alone. ${ }^{8}$

If the Messe des pauvres, as seems likely, was conceived as a missa brevis, that is, a Mass consisting of Kyrie and Gloria, with additional-perhaps optionalmovements for voices and organ as well as for organ alone, ${ }^{9}$ it could have been performed successfully in a liturgical setting; moreover, the lost Gloria seems to have been in existence in 1895, for it is mentioned by Conrad Satie. ${ }^{10}$ Unfortunately, the Gloria was not published as a part of the Mass, for whatever reasons, and apparently was not among the papers left by Satie at his death.

Would it be possible to reconstruct the lost Gloria to make the Messe des pauvres a viable missa brevis? It would seem that no manuscript material for the Gloria is extant. However, among the keyboard pieces contemporaneous with the Mass-pieces not published by Satie in his lifetime-the posthumous

4The first four systems of the printed edition seem to correspond with the Prélude mentioned by Conrad Satie in 1895; indeed, in a preliminary draft (Paris, BN MS $9597^{(1)}$, pp. $28-22$ [the manuscript was inverted for this entry]), a double bar marks the end of the Prélude.

5The "Dixit Dominus" was perhaps meant to be a four-voice "fauxbourdon" setting of Psalm 109. The text and underlay are garbled. Nothing precludes the singing of additional verses of the Psalm and the lesser Doxology.

6 The movement is lost. See Orledge, Satie the Composer, 279.

7 Two harmonizations are given in the printed edition. Orledge states that Satie intended the second harmonization to be his final version. See Orledge, Satie the Composer, 279.

8Patrick Gowers, "Satie's Rose Croix Music (1891-1895)," Proceedings of the Royal Music Association 92 (1965-66): 23, labels this procedure "Cantor/choir."

9The rubric "avec petit chœur soprano-basse ad lib." that appears in the catalogue that Salabert append to their prints of Satie's music may simply be a publisher's "gimmick" for increasing sales.

10See Myers, Erik Satie, 29 f., and Orledge, Satie the Composer, 278. Conrad Satie's description of the Messe des pauvres, which appeared in Le Cour 2, no. 10 (June 1895), is translated in Myers: "It opens with a very characteristic Prelude which forms the basis of the Mass and consists of 'motets' [sic] which occur again and again all through the service and are repeated by the organ and by the choir. Between the Kyrie and the Gloria a Prayer is interpolated called the Organs' Prayer. Through the voices of men and children the faithful implore pity; but it is for the organ to gather up all these cries of distress and to convey to the Creator the prayer of the whole assembly...." 
Premier prélude du Nazaréen ${ }^{11}$ suggests itself as a source for the music of the lost Gloria. The Prélude, which is given a very detailed and complete analysis by Robert Orledge, ${ }^{12}$ employs what Patrick Gowers has christened "punctuation form." 13 The Prélude is made up of thirteen longish melodic-harmonic phrases, each of which contains a variety of melodic and rhythmic motifs. Each phrase is concluded with a four-chord "punctuation mark." The relation of the Prélude to the text of the Gloria in excelsis was apparent to me only after consulting Willi Apel's analysis of the plainchant Gloria V. ${ }^{14}$ Apel's commentary is worth quoting at length:

\begin{abstract}
A rather strange application of the repeat form is found in Gloria V. Practically the entire melody consists of nothing but a single phrase which is reiterated eleven times, but with a complete disregard of the textual structure. The phrase itself can be divided into three motives $(a, b, c)$ which can best be seen in connection with the verse Gratias (a) agimus tibi (b) propter magnam gloriam tuam (c). Only in this and three other verses of similar length (Domine ... omnipotens, the second Qui tollis, and Qui sedes) does the musical phrase coincide with a textual one. Usually the repetition of music cuts right across the textual divisions, so that some verses start with motive $b$, others consist only of $\mathrm{a}+\mathrm{b}$, yet others of $\mathrm{c}+\mathrm{a}$. ... Only in the initial Gloria, the words bonae voluntatis, and its closing -men stand outside this rigid repeat scheme.
\end{abstract}

Orledge finds that there are four distinct melodic motifs used in the Premier prélude du Nazaréen. Motif $\mathrm{A}$ is thirteen quarter-note beats long and is not combined with other motifs. Motif $A^{\prime}$ is A extended to seventeen beats. Motif $B$ is eleven quarter-note beats long, but can be shortened to ten beats. Motif $B$ combines with itself and motif $C$. Motif $B^{\prime}$ is the first two chords of $B^{15}$ and serves as a varied beginning for motif $C$. Motif $C$ is seven quarter-note beats long and combines with motif $\mathrm{D}$. Motif $\mathrm{D}$ is four quarter-note beats long, but can be expanded to five beats. It combines with motifs $C$ and $B^{\prime}$. Motif $P$ is the punctuation phrase.

The thirteen phrases of the Prélude and the textual incipits of the Gloria, also divided into thirteen parts, are shown in table 1.

11 According to the New Grove, s.v. "Satie," Darius Milhaud negotiated the publication of a number of Satie's early works after his death. (See note 1.) Éditions Salabert-the successors to RouartLerolle-retain the Rouart-Lerolle plate numbers and copyright notices in their recent collected edition of Satie's piano music entitled Erik Satie: Piano Solo (Paris: Salabert, 1989). By examining the plate numbers I was able to determine which pieces Milhaud had prepared for publication. In 1929, Rouart-Lerolle published six works by Satie: Danses gothiques (1893), R-L plate number 11685; La Messe des pauvres (1893-95), 11686; Les patins dansent (1913), 11687; the Passacaille (1906), 11688; Quatre préludes (1888-92), 11689; and the Prélude en tapisserie (1906), 11690. (The Premier prélude $d u$ Nazaréen is the third of the Quatre préludes.)

12Orledge, Satie the Composer, 146-50. His figures 4.1 and 8.2 show the beginning and end of the Prélude in Satie's autograph.

13Gowers, "Satie's Rose Croix Music," 18.

14Willi Apel, Gregorian Chant (Bloomington: Indiana University Press, 1966), $411 \mathrm{ff}$.

15 What Orledge labels $D$ (last 2 chords) in his figure 8.1 is actually the first two chords of $B$ : a D minor chord in first inversion moving to a $C$ major triad. (The last two chords of $D$ are an $F$ major triad moving to a $\mathrm{C}$ major triad.) 
Table 1: Comparison of the Structure of the Premier prélude du Nazaréen and the Text of the Gloria in excelsis

Premier prélude du Nazaréen

Motifs and number of beats

1. A P

134

2. $\mathrm{A}^{\prime} \quad \mathrm{P}$

$\begin{array}{ll}17 & 4\end{array}$

3. A P

134

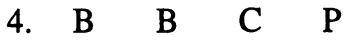

$\begin{array}{llll}10 & 11 & 7 & 4\end{array}$

5. D C C P

$\begin{array}{lll}4 & 7 & 4\end{array}$

6. $\begin{array}{llllll}\mathrm{D} & \mathrm{C} & \mathrm{D} & \mathrm{B}^{\prime} & \mathrm{C} & \mathrm{P}\end{array}$

$\begin{array}{llllll}5 & 7 & 5 & 2 & 7 & 4\end{array}$

$\begin{array}{llllllll}\text { 7. } & \text { B } & \text { C } & \text { D } & \text { C } & \text { D } & C^{\prime} & \text { P }\end{array}$

$\begin{array}{lllllll}11 & 7 & 4 & 7 & 4 & 6 & 4\end{array}$

8. B C P

$\begin{array}{lll}11 & 7 & 4\end{array}$

9. $\mathrm{D} C \mathrm{C} \quad \mathrm{P}$

$\begin{array}{lll}4 & 7 & 4\end{array}$

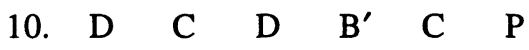

$\begin{array}{llllll}5 & 7 & 5 & 2 & 7 & 4\end{array}$

11. A P

134

12. $\mathrm{A}^{\prime} \mathrm{P}$

$\begin{array}{ll}17 & 4\end{array}$

13. A $\quad \mathrm{P} \quad \mathrm{P} \quad \mathrm{D}$ minor chord

$\begin{array}{llll}13 & 4 & 4 & 2\end{array}$
Gloria in excelsis

Total Clauses

Gloria ...

Deo.

Syllables

17

Et in terra ...

voluntatis.

Laudamus te ...

Glorificamus te. 21

Gratias agimus ...

gloriam tuam.

Domine Deus ...

omnipotens.

Domine Fili ...

Jesu Christe.

14

Domine Deus ...

Filius Patris.

14

Qui tollis ...

miserere nobis. 14

Qui tollis ...

nostram.

Qui sedes ...

miserere nobis.

14

Quoniam ...

Dominus.

14

Tu solus ...

Jesu Christe.

11

Cum Sancto ...

Patris. Amen. 16

I have labelled the motifs of the Prélude and indicated the number of beats. The incipit of each clause of the Gloria is followed by a syllable-count. Only three clauses of the text have more syllables than the music has beats, but the extra syllable can be accommodated by breaking some of the quarter-note beats into eighth-notes. The rest of the lines of the Gloria allow some melismatic treatment of single words, such as "Fili" in clause 6, "Filius Patris" in clause 7, and "Jesu Christe" in clause 12.

As can be seen from table 1, the Prélude and the Gloria text have similar structures, and are extraordinarily compatible. Note that such major textual divisions as "Gratias agimus tibi" and "Quoniam tu solus sanctus" are accompanied by new motifs. My adaptation of the text of the Gloria to the melodic line of the Prélude can be seen in example 1. (Where I have broken up notes to accommodate syllables, the original value is placed above the staff.) The music of the Prélude, with its quasi-plainchantesque melodic cells, seems 
ideally suited to the text, and the "punctuation phrase" sets each clause of the Gloria into relief. What is more, the D minor chord at the end of the Prélude, which seems a little forced in the piano version, now seems to make a real musical point following the choir's "Amen."16

Movement 3 of Satie's Messe des pauvres is a "fauxbourdon" setting of his own "neo-gregorian- cum-gypsy-minor" psalm-tone formula. The text printed with the music is faulty; it should read "Dixit Dominus Domino meo: Sede a dextris meis," as Orledge has pointed out. ${ }^{17}$ ("Dixit Dominus," Psalm 109, is the first psalm at Sunday Vespers.) Satie produced several versions of number 3. He published one version in his own beautiful Gothic calligraphy as "Intende votis supplicum," and the music is in square notation on four-line staves. ${ }^{18}$ It differs from "Dixit Dominus" in several ways.

1. The organ is specified, and the music is laid out on three staves.

2. It is pitched an octave lower than "Dixit Dominus"; however, the octave transposition was necessitated by the use of the plainchant $\mathrm{C}$ and $\mathrm{F}$ clefs on the third and fourth lines. Such apparent octave transpositions are common in figural music transcribed into chant notation by religious houses in the seventeenth, eighteenth, and nineteenth centuries, but they do not necessarily indicate real transposition.

3. All four triads on G are major triads in "Intende votis," whereas only the last triad is major in the printed edition of number 3.

4. No text is underlaid in "Intende votis."

A somewhat simpler setting of "Dixit Dominus" for organ and voices is printed in facsimile in La Revue musicale in 1952, facing page 80. This version is also in square notation on three staves, but the text is distributed to make the "fauxbourdon-style" performance clear. The first chord of each phrase is notated as a longa which is sustained until all the text that goes with it has been sung. ${ }^{19}$

The problems with number 3 of the Messe des pauvres are many. (1) Its text is garbled in the printed edition. (2) Mainly because it is so short, the piece

16Orledge describes Satie's search for a final chord. At first he tried an E minor triad, but crossed it out. He next tried a $\mathrm{G}$ minor triad, and crossed that out. Finally, he hit upon the D minor chord which ends the Prélude. Orledge comments: "The one solution he did not consider (of course) was to resolve his dominant ninth on F onto its expected tonic of B-flat major." Satie the Composer, 148. The crossed-out chords can be seen in his figure 8.2.

17 See note 1. In Satie's manuscript (Paris, BN MS $9597^{(1 \mathrm{bis})}$, fol. 10r) a very rough draft of the music has the text "Dixit ... meis" fitted syllabically, one syllable to one chord; however, there was too much text for the music, and "dextris meis" was left hanging. Satie reset the text, perhaps working backward, so that music and text come out together, but the extra words were squeezed in the middle of the verse. For his third attempt, he recopied the music and underlaid the text almost exactly as I have done in my example 2.

18See Nigel Wilkins, The Writings of Erik Satie (London: Eulenburg Books, 1980), 42, for a facsimile of "Intende votis supplicum."

19 See Orledge, Satie the Composer, $279 \mathrm{f}$., for further information about the manuscript sources for the three versions. 

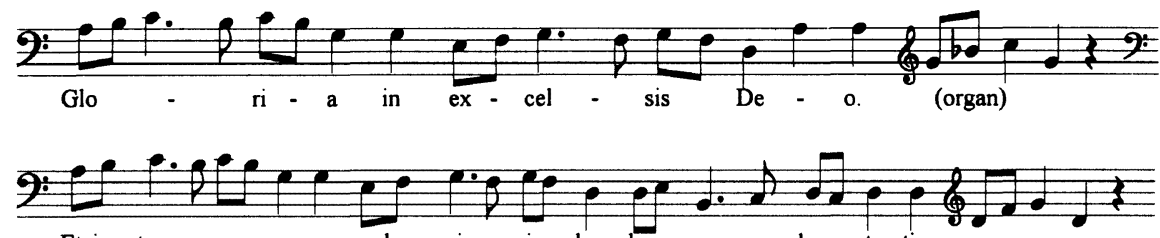

Et in ter - - ra paxho- mi - ni - bus bo - næ vo - lun - ta - tis. (organ)
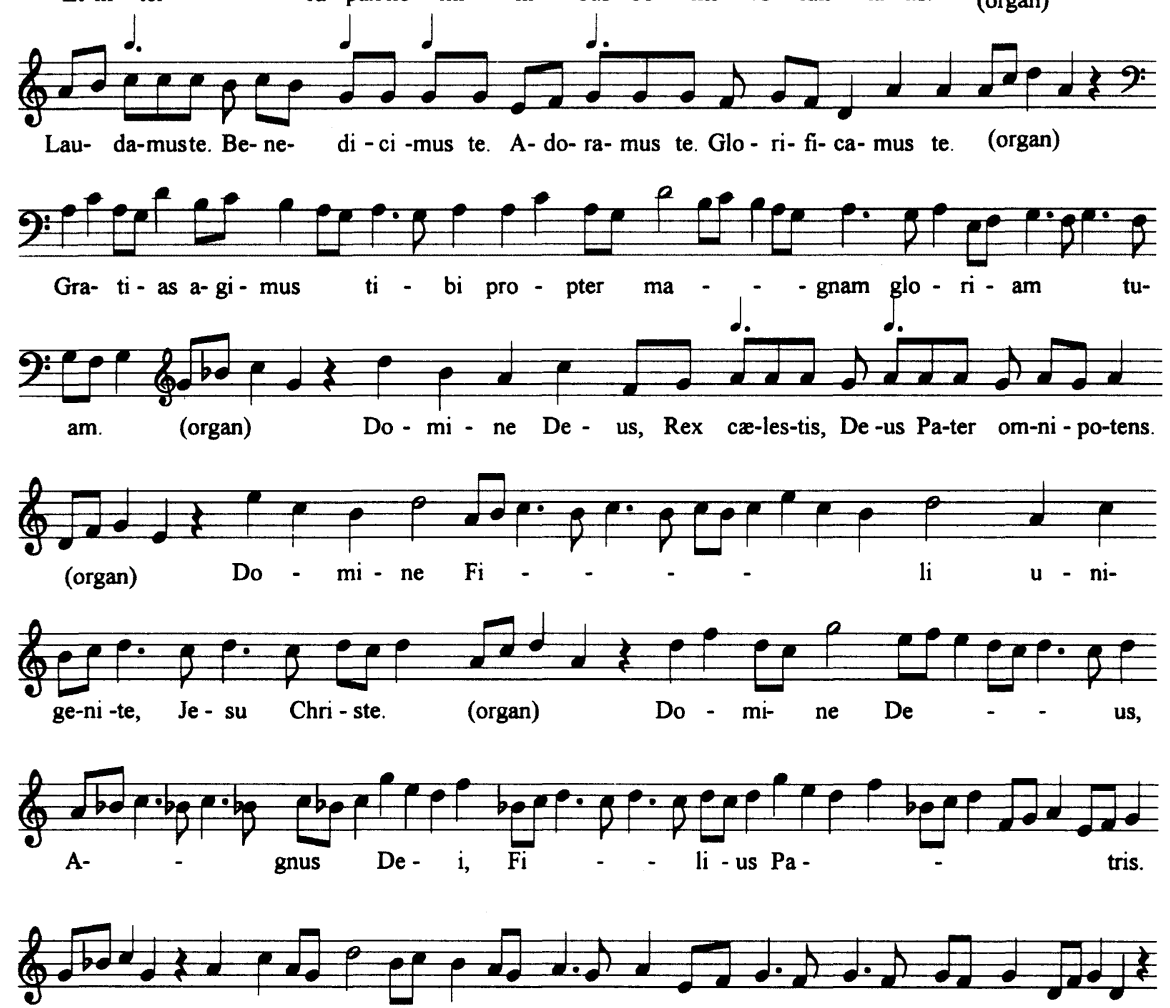

(organ) Qui tol - lis pec - ca-ta mun - di, mi-se-re - re - no - bis. (organ)

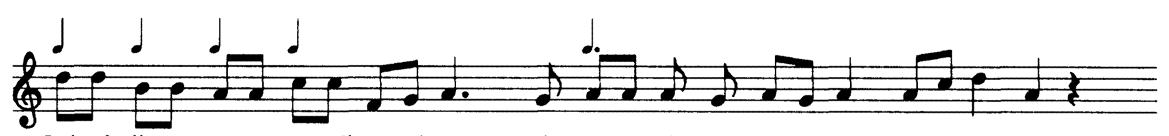

Qui tol-lis pec-ca - ta mun-di, su-sci-pe de-pre- ca-ti- o-nem no-stram. (organ)

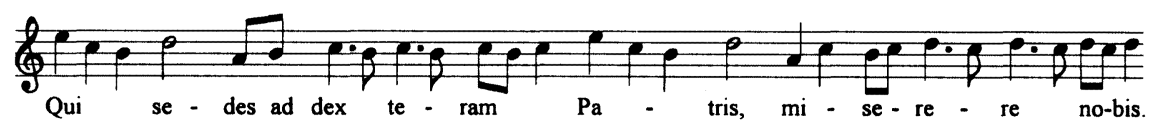

Example 1: Prélude with Gloria text (melodic line only) 

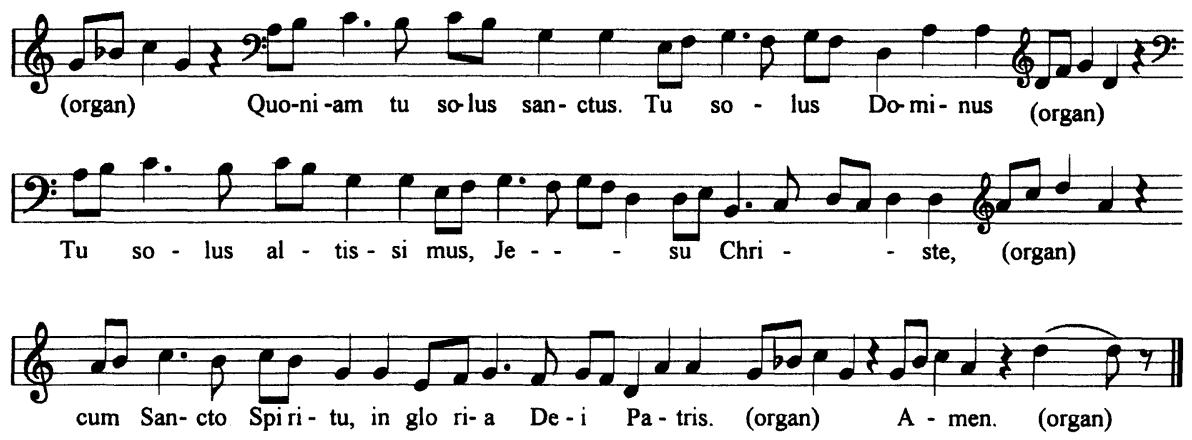

Example 1 - Continued

lacks a sense of purpose. (3) The roles of organ and voices in the setting are unclear. ${ }^{20}$ (4) Its liturgical function is unknown, for none of the items of the Proper of the Mass uses a psalm-tone formula all by itself. ${ }^{21}$

The first verse of Psalm 109 is long, and at Sunday Vespers is always sung as two separate verses. ${ }^{22}$

Dixit Dominus Domino meo:* "Sede a dextris meis:

Donec ponam inimicos tuos,* scabellum pedum tuorum."

(The Lord said to my Lord: "Sit thou at my right hand, until I make thy enemies thy footstool.")

Thus, in order to complete the sense of the half-verse that appears in the printed edition of the Messe des pauvres, the rest of the verse could be accommodated by simply repeating Satie's music for the remaining text. The lesser Doxology could be added as well. The cantor(s) and organ intone the psalm "Dixit Dominus Domino meo," and the choir continues in unison or parts, with the organ accompanying. My adaptation of the "Dixit Dominus" is shown in example 2.

20Marilyn Mason's recording of the Messe des pauvres (CPT 570) allots the highest line to the soprano. They sing the garbled text of the printed version, accompanied by Mason in four parts. Gaston Litaize's CD (EMI CZ 62877) has the choir singing in four parts doubled by the organ. Again, the choir sings the garbled text.

21 It is not impossible that Satie's psaume was composed as "generic" music for the psalm-verse of an Introit to be selected by the performers. The text would, of course, be that associated with the Introit Antiphon, and the movement would thus be the first item of the Messe des pauvres. Could Satie have planned "fauxbourdon" settings of the five psalms of Sunday Vespers? There seems to be no record of such a project.

22The Liber usualis (Tournai: Desclée, 1952), $128 \mathrm{ff}$., numbers the two halves of the first verse as Verse 1 and Verse 2; the text of the psalm is underlaid to each of the psalm-tones. 

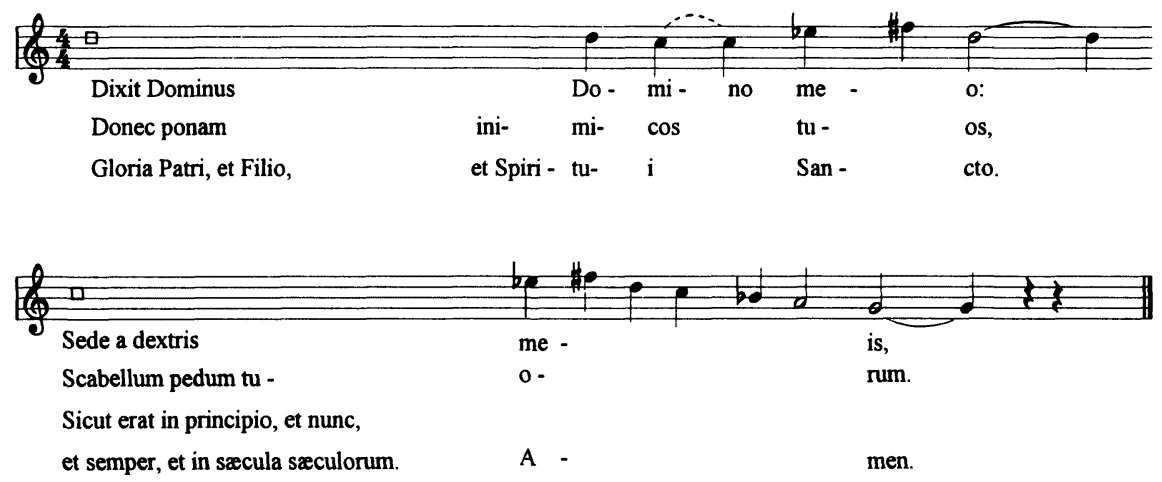

Example 2: "Dixit Dominus" with corrected text (melodic line only)

Two other short movements of the Messe des pauvres, the "Chant ecclésiastique" (number 7) and the two versions of the "Prière pour les voyageurs" (number 8 ), also seem to be unfinished or incomplete. They may have been meant, like the "Dixit Dominus," to have texts. In comparison with the "Prière des orgues" (number 4 ), or the "Prière pour le salut de mon âme" (number 9), these two movements cannot be regarded as self-sufficient organ pieces. ${ }^{23}$

Here, as in the "Dixit Dominus," Satie seems to have been cultivating a "neo-gregorian" melodic style, and experimenting with different kinds of harmonizations for his supple chant-like melodies. ${ }^{24}$ If the singers are to be further involved in the Messe des pauvres, suitable texts will need to be supplied. For the "Chant ecclésiastique," verse 27 of Psalm 21 seems to suit the melody and the rhythm of Satie's "Chant":25

Edent pauperes, et saturabuntur;

Et laudabunt Dominum qui requirunt eum.

(The poor shall eat and be satisfied,

and they shall praise the Lord, who seek Him.)

This verse tells of the Lord's bounty to the poor, who, apart from the title of the Mass, are otherwise ignored by Satie. The twenty-four-syllable verse is easily accommodated to Satie's music (example 3).

23Gillmor, Erik Satie, 355, notes that some of the "slighter" movements of the Messe des pauvres are omitted in recorded performance.

24For information about the possible plainchant influences on Satie's music, see Gillmor, Erik Satie, 90; Orledge, Satie the Composer, 37-38; and Gowers, "Satie's Rose Croix Music," 23.

25 This verse is part of the "Benedictio mensæ" (blessing at table) given in the Breviarium romanum, pars verna (New York: Benziger, 1906, [236]). The Concordance to the Vulgate yielded a number of verses that mention the poor, but only the verse I have chosen has a syllable-count and accentuation that fit Satie's music. 

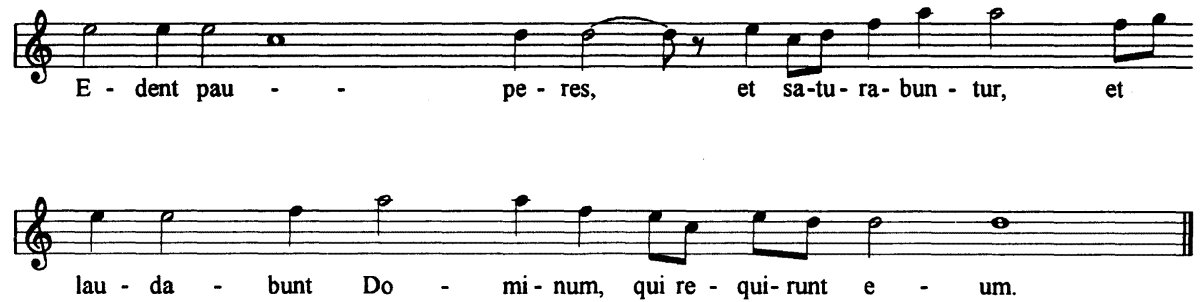

Example 3: "Chant ecclésiastique" with added text (melodic line only)

For the first harmonization of the "Prière pour les voyageurs," a short petition from the office of Our Lady, Mediatrix of all Graces ${ }^{26}$ seems to be a match for Satie's musical "prière," for it speaks of succour and deliverance by the glorious Virgin:

A periculis cunctis libera nos semper,

Virgo gloriosa et benedicta.

(Deliver us from all dangers,

$O$ ever glorious and blessed Virgin.)

Again, its twenty-four-syllable text fits comfortably with Satie's music (example 4).
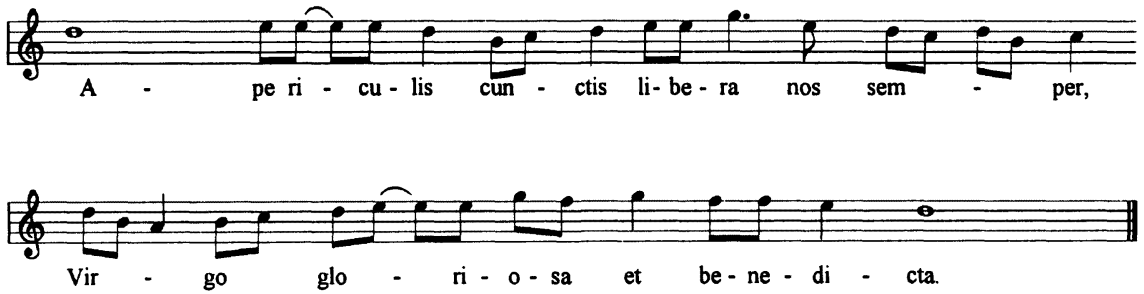

Example 4: "Prière pour les voyageurs" with added text (melodic line only)

One possible way of performing the "Prière pour les voyageurs" would be to begin with the second harmonization played by the organ alone, continue with the first harmonization sung in unison or parts by the choristers, and to finish with a repeat of the second harmonization by the organ.

26The Office and Mass of this feast are to be found in the Liber usualis, "Supplement for Certain Religious Congregations." The text is used for the short respond at None. An examination of the Antiphons of various feasts of the Blessed Virgin yielded several possible texts. The one I have chosen fits Satie's music the best. 
That I have adapted a piano prélude to serve as the Gloria of Satie's Messe des pauvres, and that I have supplied the Latin texts for three other movements of the Mass may raise some eyebrows. The Mass, however, as it stands in the printed edition, must be regarded as a magnificent torso left incomplete by the composer. What Satie's ideas about the Mass were is something we shall never know, but with a composer as enigmatic as Erik Satie, we are entitled to speculate what the work would be like in a more finished state. Such speculation may lead to discoveries concerning Satie's working methods. Madame Ornella Volta, the president of the Fondation Erik Satie (Paris), is beginning to think that Satie may have composed pieces to texts known only to himself. Although no trace of such a method of composing is to be found in his notebooks, Mme Volta posits that such a procedure would be typical of the esoteric composer. She suggests that the idea of Satie's composing to "secret" or "hidden" texts may lead to new and unsuspected ways of looking at his music. ${ }^{27}$

Whether Satie had such texts in mind when composing the Messe des pauvres is an open question, but the texts I have supplied fit the music and add a new dimension to the work. With the Gloria in excelsis restored to the Mass, the "Dixit Dominus" emended to a usable state, and the two other "neo-gregorian" movements provided with the text to be sung, it is to be hoped that choirs and organists everywhere will take pleasure in performing Satie's only sacred work, the wonderful Messe des pauvres. ${ }^{28}$

\begin{abstract}
Erik Satie worked on his Messe des pauvres from 1893 to 1895 but never completed it. After Satie's death, Darius Milhaud selected movements from the composer's notebooks and published them in 1929 as the Messe des pauvres for organ and voices. The Mass is missing its Gloria; however, the only contemporary account suggests that the Gloria was in existence in 1895. The object of this article is to propose a new Gloria based on one of Satie's contemporaneous piano préludes. As well, to involve the singers more fully, two very short movements are furnished with Latin texts.
\end{abstract}

27 Private communication from Mme Ornella Volta, 11 September 1997.

28My new version of the Messe des pauvres was performed on 5 November 1997 by the Sonic Lab of the School of Music, University of Victoria, and was broadcast on the CBC II (FM) on 12 March 1998 (Eric Friesen "In Performance"). 